\title{
BIOLOGICAL EVALUATION OF GINGER RHIZOMES, AND GARLIC BULBS EXTRACTS
}

Gehan A. Goneim ${ }^{1}$; M. A. Hussien ${ }^{1}$;Ghada Z. A. Soliman ${ }^{2}$ and A. S. Essia ${ }^{1}$. 1 Food Industries Dept., Fac. of Agric., Mansoura University, Egypt

2 National nutrition institute, Cairo., Egypt

\section{ABSTRACT}

The study aimed to use two extracts from garlic and ginger at different four doses $(50,100$ and $200,400 \mathrm{mg} / \mathrm{kg}$ ) for ginger and garlic, respectively, and the extracts were used to decrease the harmful effect of over toasted bread. The extracts were added to the basal diet containing $10 \%$ over toasted bread. Thirty -six male albino rats were used in the animal experiment and the rats received tested diets and water in groups (1-6) for 30 days. The rats' weights and the eaten and uneaten food were recorded then blood samples were collected in tubes containing EDTA for blood analysis. The obtained results throughout chemical analysis for plant samples and the blood can be summarized as follows:

Our results showed that in ginger total carbohydrates, lipid, protein, ash and fiber were higher than garlic sample, but the content of moisture and vitamin $C$ was higher in garlic sample than ginger sample and the contents of iron, phosphorus, calcium, potassium, zinc and total content of polyphenols and flavonoids in ginger sample were higher than garlic sample. As well as, fourteen polyphenols were detected in the two samples except catechein and salicylic acid. Pyrogallic acid was the highest polyphenol in garlic and ginger samples, respectively. In addition, most flavonoids were found in garlic and ginger samples, garlic has higher content of rutin, luteolin, querectrin, hypersoid and their values were 5.31, 32.53, 20.48, 13.99 ppm respectively than ginger. Also, our results revealed that the content of acrylamide in over toasted bread was $315.7 \mathrm{microgram} / \mathrm{g}$ of sample and over toasted bread did not appear any effect on the body weight gain, daily food intake, and food conversion ratio. In addition, over toasted bread did not change the levels of total protein, albumin, globulin, antioxidant capacity and glucose, the change was not significant $P<0.05$. So, the plant extracts (ginger and garlic) have got therapeutic effect for increasing both hemoglobin and hematocrit to normal level, while over toasted bread in positive group led to increase the levels of liver enzymes ,total cholesterol ,LDL,VLDL, triglycerides and decrease SOD level, but the sixth group which contains $(400 \mathrm{mg} / \mathrm{kg} \mathrm{b.w)} \mathrm{could} \mathrm{successfully} \mathrm{decrease} \mathrm{previous} \mathrm{blood} \mathrm{parameters} \mathrm{and}$ increase SOD level.

Keywords: Ginger, garlic extracts, over toasted bread, polyphenols.

\section{INTRODUCTION}

Consumption of plant -derived foods, especially fruits and vegetables has been linked to decrease risk of cancer. Laboratory studies with animals and cells in culture have shown cancer preventive activity of chemicals isolated from green, yellow, orange fruits and vegetables. (Dong 2000). Since ancient times, spices and herbs have been used for preventing food spoilage and deterioration, and for extending shelf life of food .Many of the spices and herbs used today have been valued for their antimicrobial effects and their medicinal powers in addition to their flavor and fragrance qualities (Ceylen and Fung, 2004) 
Ginger (Zingiber Officinale Roscoe, Zingiberacae) is one of the most commonly used spices around the world, especially in the South Eastern Asian countries. Ginger is also a medicinal plant has been widely used in Chinese, Ayurvedic (Indian complementary medicine) and Unani-Tibb medicines. Since antiquity, for a wide group of ailments(diseases) that include arthritis, rheumatism, sprains, muscular aches, pains, sore throats, cramps, constipation, indigestion, vomiting, hypertension, dementia , fever, infectious diseases and helminthiasis (Dedov et al., 2002).

Ginger has been demonstrated to have various pharmacological activities such as antiemetic, antiulcer, unti-inflammatory, antioxidant, antiplatelet, glucose- and lipid - lowering, cardiovascular and anti-cancer activities (Shukla and singh, 2007).

Garlic (Allium Sativum) is used as a vegetable spice and medicinal herb. Recent research on garlic has used it in the form of tablets, fresh, dried raw, boiled and cooked preparation (Gorinstein et al., 2006). Commercially available garlic preparations in the form of garlic oil, powder and pills are also widely used for therapeutic purposes. Garlic exhibits a wide range of properties including immunomodulatory, hepatoprotective, antimutagenic, anticarinogenic, and antioxidant effects (Horie et al., 1989) and (Al-Numair, 2009).

Over toasted bread contains acrylamide. Long-term exposure to acrylamide may cause damage to the nervous system both human and animals to a certain extent (Tilson, 1981), and acrylamide is also considered as a potential genetic and reproductive toxin (costax et al., 1992), with mutagenic and carcinogenic properties in experimental mammalians both in vitro and in vivo study (Dearfield et al., 1995).

The aim of this study is to evaluate ginger rhizomes, and garlic bulbs extracts as anticarcinogenic effects.

MATERIALS:

\section{MATERIALS AND METHODS}

Precarcinogenic diets:-

Bread: bread was over toasted until brown color in an oven at 140-150 $\mathrm{C}^{\circ}$

Antioxidant plants: such as ginger rhizomes, and garlic bulbs. market.

Bread and antioxidant plants: were bought from local Mansoura Cairo.

Solvents: were obtained from Gomhoreha Company for chemicals in

Animals: thirty -six male albino rats weighting between (182-252gm) were obtained from the animal house of National Research Institute, Cairo, Egypt.

\section{METHODS:}

Chemical analysis:

Moisture, crude fibers, ash, crude protein, crude fat, ascorbic acid, Iron, and Phosphorus contents were determined according to A.O.A.C. (2009). Carbohydrates were calculated by differences. Minerals ( $\mathrm{Ca}, \mathrm{K}, \mathrm{Cu}$, and $\mathrm{Zn}$ ) by using Atomic adsorption spectrometry Berkin Elemer (2380Ass) according 
to A.O.A.C. (2000). Total phenolic compounds were determined according to A.O.A.C (2000). Total flavonoids was determined as $\mathrm{mg}$ catechin $/ 100 \mathrm{~g}$ sample according to Ivanova et al. (2010), while identification of phenolic compounds were determined by HPLC according to the method of Goupy et al. (1999) and Flavonoid compounds were determined by also HPLC according to the method of Mattila et al., (2000). Total acrylaminde in over toasted bread was determined as described byWang et al., (2008).

Preparation of ginger extract:

The plant was dried in the shade. The dried rhizome was powdered mechanically and extracted by cold percolation with $95 \%$ ethanol for $24 \mathrm{~h}$. The extract was recovered and 95\% ethanol was further added to the plant material and the extraction continued. The process was repeated three times. The three extracts were collected together and the combined extract was concentrated under reduced pressure $(55 \mathrm{mmHg})$ at $45-60 \mathrm{C}^{\circ}$. Solvent free extract $(30 \mathrm{~g})$ was equivalent to $1 \mathrm{~kg}$ of dried ginger powder $(\mathrm{W} / \mathrm{W})$.The concentrate was weighed and the dose equivalent to $200 \mathrm{mg}$ of the crude plant $/ \mathrm{kg}$ body weight (W/W) was calculated. The extract was prepared according to Bhandari et al., (1998).

Preparation of garlic extract:

Garlic was peeled and dried in an oven (Galen Kamp) at $55 \mathrm{C}^{\circ}$ for $3 \mathrm{~h}$. The dried garlic was ground to pass through a $1 \mathrm{~mm}$ sieve and about $5.0 \mathrm{~g}$ of garlic was extracted by $150 \mathrm{ml}$ of each solvent methanol, ethanol, diethyl ether, acetone, hexane and ethyl acetate, extracts then subjected to shaking at room temperature over night at a speed of $1000 \mathrm{vib} / \mathrm{min}$. The extracts were filtered and residue was again extracted with $100 \mathrm{ml}$ of each solvent .This procedure was repeated three times to ensure the complete extraction of phenolic compounds. Then, the filtrate was subjected to rotary evaporation at $40 \mathrm{C}^{\circ}$ under reduced pressure for drying and removal of solvent. The extracts were weighed to calculate the yield and were stored under $-20 \mathrm{C}^{\circ}$ before adding the extract to the diet according to lqbal and Bhanger, (2007).

Yield of extracts:

Ginger rhizomes were extracted by ethanol, while garlic was extracted by methanol, ethanol, diethyl ether, acetone, hexane and ethyl acetate. Yield of extracts was $9 \%$, and $2.5 \%$ for garlic bulbs and ginger rhizomes, respectively. Plant extracts yield was calculated on dry weight basis.

\section{Design of biological experiment:}

Thirty - six male albino rats were housed in stainless steal wire cages under normal healthy conditions and fed one basal diet for 7 days as adaptation period. Diets were offered to the rats in a special non-scatting feeding cup to avoid loss of food and contamination. Tap water provided to rats by mean of glass tubes projecting through wire cages from inverted bottles supported to one side of the cage. The composition of basal diet $(\mathrm{g} / \mathrm{kg})$ according to Reeves et al, (1993) (AIN - 93G diet) consist of cornstarch(397.486), casein(200), dextrinized cornstarch(132), sucrose(100), soybeanoil(70), fiber(50), mineralmix(35), vitamin $\operatorname{mix}(10)$, L-cystine(3), choline bitartrate(2.5), tert-butylhydroquinone ( 0.014$)$. After adaptation period (7 days) animals were fed on different tested diets for thirty (30) days 
and the body weight was recorded on days $0,7,14,21,28$ of the experiment. The diet and uneaten food were weighed every day. Rats were fasted overnight, anesthetized using diethyl ether and the blood was collected from the orbital venous plexus by capillary tube into tube containing EDTA for analysis. The blood samples were centrifuged at 5000 r.p.m for $15 \mathrm{~min}$ to separate serum, and then kept in plastic vials at $-20 \mathrm{C}^{\circ}$ until analysis. Liver, kidney, tests, brain, spleen, and heart were separated, weighed then kept in saline solution and stored at $-20^{\circ} \mathrm{C}$ until histopathological examination. The rats were divided into eight groups (six rats in each group) as follows:

Group (1): control rats were fed basal diet (negative control).

Group (2): rats were fed basal diet contains 10\% over toasted bread (positive control).

Group (3): rats were fed basal diet contains 10\% over toasted bread and ginger extract corresponding to $50 \mathrm{mg} / \mathrm{k} . \mathrm{g}$ body weight / day.

Group (4): rats were fed basal diet contains $10 \%$ over toasted bread and ginger extract corresponding to $100 \mathrm{mg} / \mathrm{k} . \mathrm{g}$ body weight / day.

Group (5): rats were fed basal diet contains $10 \%$ over toasted bread and garlic extracts corresponding to $200 \mathrm{mg} / \mathrm{k} . \mathrm{g}$ body weight / day.

Group (6) rats were fed basal diet contains $10 \%$ over toasted bread and garlic extract corresponding to $400 \mathrm{mg} / \mathrm{k} . \mathrm{g}$ body weight / day.

\section{Biochemical Assays:}

\section{Determination of Glutamic pyruvic transaminase (GPT) activity:}

Glutamic pyruvic transaminase (GPT) was determined according to the method described by Reitman and Frankel (1957).

Determination of Glutamic oxaloacetic transaminase (GOT) activity:

Glutamic oxaloacetic transaminase (GOT) was determined according to method of IFCC (1977).

\section{Determination of serum triglycerides:}

Triglyceride measurements are used in the diagnosis and treatment of diseases involving lipid metabolism and various endocrine disorders e.g. diabetes mellitus, nephrosis and liver obstruction. Triglycerides are determined after enzymatic hydrolysis with lipases as described by Trinder et al., (1969).

\section{Determination of serum total cholesterol:}

Total Cholesterol was determined by enzymatic colorimetric method using kits provided from Beta Lap. Company according to Trinder , (1969) . Determination of high density lipoprotein cholesterol (HDL - cholesterol) in serum:

Low density lipoprotein (LDL) cholesterol and very low density lipoprotein (VLDL) cholesterol fractions are precipitated from serum or plasma by means of a magnesium chloride dextran sulfate reagent, according to (Finley et al., 1978). High density lipoprotein (HDL) cholesterol is then determined in the supernatant fluid, using a cholesterol reagent and the derived dilution factor in the calculation. 
Calculation of low density lipoprotein cholesterol (LDL - cholesterol): LDL can be calculated according to (Friedewald et al., 1972) as follows:

$\mathrm{LDL}(\mathrm{mg} / \mathrm{dL})=$ Total cholesterol $-\mathrm{HDL}-\frac{\mathrm{TG}}{5}$

Calculation of very low density lipoprotein cholesterol VLDLcholesterol:

V-LDL was estimated by the following equation :

$\mathrm{V}$-LDL $(\mathrm{mg} / \mathrm{dL})=$ Total cholesterol- $(\mathrm{HDL}-\mathrm{C}+\mathrm{LDL}-\mathrm{C})$.

Determination of serum glucose:

Glucose was determined using a colorimetric enzymatic method. The method is based on the hydrogen peroxide indicator reaction which couples 4 - aminoantipyrine to phenolic compound as first proposed by (Trinder et al. 1969). This method has been validated in an expensive study by Penock et al (1973)

Determination of serum total protein:

Serum total protein was determined according to (Tietz et al. 1970). Determination of Albumin:

Colorimetric determination of albumin in serum or plasma samples was performed according to Doumas et al. (1971).

Determination of food conversion (FCR):

Food conversion ratio (FCR) was determined using the following equation according to Youssef et al, (1995).

$$
\text { F.C.R }=\frac{\text { Daily food consumed }(g)}{\text { Dialybody weight gain }(g)}
$$

Determination of total antioxidant capacity:

Total antioxidant capacity was determined by colorimetric method according to koracevic et al. (2001).

Determination of hematocrit: (1954).

Hematocrit was measured using heparinzed tube according to Inory

\section{Determination of blood superoxide dismutase:}

It is based on the method of Beachamp \& fridovich, (1971) and depends on the ability of the enzyme to inhibit the reduction of nitroblue tetrazolium (NBT) by the reaction of photoreduced riboflavin and oxygen.

Determination of hemoglobin:

Hemoglobin was determined by a colorimetric method according to Franco et al. (1984).

Statistical analysis:

The results were analyzed by the analysis of variance (ANOVA) using the procedure by Statistical Analysis System (SAS) program according to $S A S$ (1996). Significant differences were determined at the level $P \geq 0.05$.

\section{RESULTS AND DISCUSSIONS}

Chemical composition of study ginger and garlic samples:

Data in table (1) showed that moisture, ash, crude protein, crude fat and total carbohydrates contents were determined in ginger and garlic 
samples. All results were calculated as ( $\mathrm{g} / 100 \mathrm{~g}$ dry weight).It was clear that ginger has low percentage values for moisture $(10 \%)$ and high values of carbohydrates, fat ,ash ,protein and fiber which were $67.6,3.5,7.2,8.7$ and $3 \%$ respectively compared with garlic bulbs which have a high moisture content $(63 \%)$

Table (1): Chemical composition of study ginger and garlic samples:

\begin{tabular}{|l|c|c|c|c|c|c|}
\hline $\begin{array}{l}\text { Raw constituents } \\
\text { materials }\end{array}$ & $\begin{array}{c}\text { Moisture } \\
\%\end{array}$ & $\begin{array}{c}\text { Crude } \\
\text { fiber } \\
\%\end{array}$ & Ash\% & $\begin{array}{c}\text { Crude } \\
\text { protein } \\
\%\end{array}$ & $\begin{array}{c}\text { Crude } \\
\text { fat } \\
\%\end{array}$ & $\begin{array}{c}\text { Total } \\
\text { carbohydrat } \\
\text { es } \%\end{array}$ \\
\hline Ginger & 10 & 3 & 7.2 & 8.7 & 3.5 & 67.6 \\
\hline Garlic & 63 & 2.5 & 1.3 & 6 & 0.3 & 26.9 \\
\hline
\end{tabular}

The obtained results by Mustafa et al.(1993) revealed that the powdered ginger rhizomes sample contains $9 \%$ protein, $60-80 \%$ carbohydrates, $3 \%$ crude fiber, $8 \%$ ash and $9-12$ water. Our results agreed approximately with previous results. As well as Blumenthal,(2000) reported that the moisture content was found to be $65 \%$, lipid content was $0.15 \%$, protein was found to be $2 \%$,carbohydrates content was $28 \%$ and fiber was found to be $1.5 \%$ in garlic bulb.

Minerals and vitamin $\mathbf{C}$ contents of ginger and garlic samples:

Elements play an important role in human nutrition. For example, phosphorus is an essential element for human bones skeleton and iron represent an important physiological function in the hemoglobin, other elements are important for activity of some enzymes and vitamins. From Table (2), it could be seen that phosphorus values were 227 and $150 \mathrm{mg}$ $/ 100 \mathrm{~g}$ while iron values were 10 and $1.5 \mathrm{mg} / 100 \mathrm{~g}$ in ginger and garlic, respectively.

Our results showed that ginger has a high content of iron, phosphorus, calcium and potassium elements. Our results did not agree with Gusev and Grishina (1963) who mentioned that iron content of garlic varied from $20 \mathrm{mg}$ to $100 \mathrm{mg}$ absolute dry weight. And also a low content of $\mathrm{K}, \mathrm{Ca}$, and $\mathrm{Zn}$ in garlic sample.

Vitamin $\mathrm{C}$ decreases risk of cardiovascular disease and it is the main water soluble antioxidant in human plasma.

The content of vitamin C was 30 and zero $\mathrm{mg} / 100 \mathrm{~g}$ in garlic and ginger rhizomes, respectively.

On the other hand, Oboh et al., (2010) mentioned that vitamin C content of the white ginger was $(0.91 / \mathrm{mmol} / 100 \mathrm{~g})$. Our results did not agree with the previous result, it may be due to the difference in the chemical analysis methods, dryness method and other factors.

Table (2): Minerals and vitamin $\mathrm{C}$ contents of ginger and garlic samples:

\begin{tabular}{|l|c|c|c|c|c|c|c|}
\hline $\begin{array}{l}\text { Raw constituents } \\
\text { materials }\end{array}$ & $\begin{array}{c}\mathbf{F e} \\
\mathbf{m g / 1 0 0} \\
\mathbf{g}\end{array}$ & $\begin{array}{c}\mathbf{P} \\
\mathbf{m g / 1 0 0} \\
\mathbf{g}\end{array}$ & $\begin{array}{c}\mathbf{C a} \\
\mathbf{p p m}\end{array}$ & $\begin{array}{c}\mathbf{K} \\
\mathbf{p p m}\end{array}$ & $\begin{array}{c}\mathbf{C u} \\
\mathbf{p p m}\end{array}$ & $\begin{array}{c}\mathbf{Z n} \\
\mathbf{p p m}\end{array}$ & $\begin{array}{c}\text { Vitamin C } \\
\mathbf{m g} / \mathbf{1 0 0 g}\end{array}$ \\
\hline Ginger rhizomes & 10 & 227 & 18.7 & 108.8 & 0.025 & 0.189 & zero \\
\hline Garlic bulbs & 1.5 & 160 & 15.8 & 28 & 0.030 & 0.182 & 30 \\
\hline
\end{tabular}

(Fe, P, Ca, K, Cu and $\mathrm{Zn}$ ) are elements of iron, phosphorus, calcium, potassium, copper, and zinc, respectively. 
Total polyphenols and flavonoids content of ginger and garlic samples: Phenolic compounds can play an important role in preventing body cells and organs from injuries by hydrogen peroxide, damage by lipid peroxides and scavenging or neutralizing free radicals. Table (3) has shown the polyphenols determined as $\mathrm{mg}$ pyrogallol equivalent / $100 \mathrm{~g}$ for investigated plant samples.

It was noticed that ginger rhizomes had high content of total polyphenols (328.9 mg pyrogallol Eq. / 100g sample) while, garlic had low value of polyphenols (180.526mg pyrogallol equivalent / $100 \mathrm{~g}$ ).

On the other hand, Bozin et al., 2008 reported that total phenol content in dried garlic bulb extract was $(0.18 \mathrm{mg}$ gallic acid (G.A) equivalent $/ 100 \mathrm{~g})$.

As well as, Oboh et al., 2010 showed that the phenol content was (61.89 mg G.A E.q / 100g) in white ginger.

Table (3): Total polyphenols and flavonoids content of investigated ginger and garlic samples:

\begin{tabular}{|l|c|c|}
\hline Extracts constituents & $\begin{array}{c}\text { Total polyphenols } \\
\text { (mg pyrogallol Eq / } \\
\mathbf{1 0 0 g})\end{array}$ & $\begin{array}{c}\text { Total flavonoids } \\
\text { (mg catechin Eq } \\
\text { /100g) }\end{array}$ \\
\hline Ginger rhizomes & 328.9 & 155.94 \\
\hline Garlic bulbs & 180.526 & 16.90 \\
\hline
\end{tabular}

E.q: equivalent

Our results showed that total flavonoids content was 155.94 and 16.90

mg catechin E.q $/ 100 \mathrm{~g}$ in samples of ginger and garlic, respectively.

Polyphenolic compounds in ginger rhizomes and garlic bulbs:

High performance liquid chromatography (HPLC) procedure was used for qualitative and quantitative analysis of polyphenolic compounds in garlic and ginger extracts. Fourteen polyphenolic compounds were found in garlic and ginger extracts. They were available at authentic samples namely: pyrogallic, chlorogenic acid, catechein, synergic, caffein, P.coumaric acid, ferulic acid, coumarin, nariginin, cinnamic, vanillic, chrisin, P. Benzoic and salicylic acid.

From Table (4), it was clear that both investigated samples contained pyrogallic, caffein, P. coumaric and ferulic acid with different concentrations. It could be noticed that pyrogallic acid was the predominant identified component in garlic and ginger at concentrations of 17258.8 and $4703.8 \mathrm{ppm}$ respectively, followed by Synergic (128.30ppm), and Ferulic acid (94.70ppm) in garlic.. While vanillic, chrisin and P.hydroxy benzoic were only found in ginger rhizomes. But in another study of Ghoneim ,2012) reported that the content of phenolic compounds in ginger ranged from 0.021 to $119.26 \mathrm{mg} / 100 \mathrm{~g}$ and values of gallic acid ,catechol ,chlorogenic, catechien , P..Benznoic, coumaric ,sallicylic, ,caffeine ,cinnamic,and chrisin were 119.26, $8.17,6.11,36.66,1.99,1.78,11.11,0.95$, and 0.021 $\mathrm{mg} / 100 \mathrm{~g}$ respectively ,but vanillic ,syringic and caffeic were not detected.

In a previous study by Rong et al. (2009) reported that the contents of 6-ginerol, 6-shogaol and galanolactone in ginger extract were quantified to be $9065.87,159.87$ and 95.38 ppm, respectively. 
Table (4) : Polyphenols of ginger and garlic extracts :

\begin{tabular}{|c|c|c|}
\hline Polyphenols(ppm) Extracts & Ginger extract & Garlic extract \\
\hline Pyrogallic & 4703.80 & 17258.8 \\
\hline Chlorogenic acid & - & 296.60 \\
\hline Catechein & - & - \\
\hline Synergic & - & 128.30 \\
\hline Caffein & 76.70 & 89.40 \\
\hline P. coumaric & 9.80 & 14.49 \\
\hline Ferulic & 77.1 & 94.70 \\
\hline Coumarin & 23.80 & 18.46 \\
\hline Nariginin & - & 31.70 \\
\hline Cinnamic & - & 9.20 \\
\hline Vanillic & 38.30 & - \\
\hline Chrisin & 22.20 & - \\
\hline P.hydroxy benzoic & 80.80 & - \\
\hline Salicylic acid & - & - \\
\hline
\end{tabular}

\section{ppm: part per million}

\section{Flavonoids of ginger and garlic extracts:}

High performance liquid chromatography (HPLC) procedure was used for qualitative and quantitative analysis of flavonoids compounds in garlic and ginger extracts. Six flavonoids compounds were available as authentic samples namely: Rutin, Luteolin, quercetrin, hypersoid apigenin and kampferol.

From Table (5), it was noticed that investigated samples contained rutin, luteolin, querectrin and hypersoid, while apigenin exhibited only in ginger extract $(78.01 \mathrm{ppm})$, and kampferol appeared only in garlic extract (26.39ppm).

Garlic extract had high concentrations from luteolin and quercetrin and their values were 32.53 and $20.48 \mathrm{ppm}$, respectively.

On the other hand, Miean and Mohamed (2001) and Leighton et al. (1992) claimed that contents of apigenin , quercetrin and myrictin in garlic extract were 217, 47 and 693ppm, respectively, While Isorhamnetin , kaempferol and luteolin were not detected. Those results differed from our results, because our results proved that kampferol and luteolin were detected in garlic extract and their values were 26.39 and $32.53 \mathrm{ppm}$, respectively. The difference due to some factors such as, irrigation, fertilization, soil, climate and chemical analysis methods.

Table (5): Flavonoids of ginger and garlic extracts:

\begin{tabular}{|c|c|c|c|c|c|c|}
\hline \multirow{2}{*}{ Extracts } & \multicolumn{6}{|c|}{ Flavonoids (ppm) } \\
\hline & Rutin & Luteolin & Quercetrin & Hypersoid & Apigenin & kampferol \\
\hline Ginger & 0.55 & 0.80 & 1.02 & 5.14 & 778.01 & - \\
\hline Garlic & 5.31 & 32.53 & 20.48 & 13.99 & - & 26.39 \\
\hline
\end{tabular}

\section{Content of acrylamide in over toasted bread sample:}

Acrylamide was determined in over toasted bread and our results have shown that the concentration of acrylamide was 315.7 microgram $(\mu \mathrm{g}) /$ gram of the sample. This value equals $0.3 \mathrm{gram} / \mathrm{kilogram}$ of the sample and also be equal to $300 \mathrm{mg} /$ kilogram of over toasted bread sample. While Wang et al.,(2008) reported that the amounts of acrylamide in eight food samples such 
as sweet potato crisps , fried sweet dumpling and sesame ball were 134, 136, and $68 \mu \mathrm{g} / \mathrm{k} . \mathrm{g}$ of the sample, respectively, and our results have shown that the amount of acrylamide in over toasted bread was too higher than the amounts obtained by them.

Effect of (over toasted bread) and antioxidant ginger and garlic extracts on body weight gain, daily food intake and food conversion ratio in rats:

Gain in body weight, daily food intake and food conversion ratio of rats fed on over toasted bread and plant extracts for a month in negative control group, positive control group and other groups fed the experimental diets are shown in Table (6). Data showed non significant changes among groups in body weight gain, daily food intake and food conversion ratio of rats compared with a positive group $(P>0.05)$.

From Table (6) It was noticed that acrylamide in over toasted bread did not appear any adverse effect on rats during the experiments.

Our results agree with Weidner andSigwart (2000) illustrated that effect of ginger extract at doses of 100,333 and $1000 \mathrm{mg} / \mathrm{kg}$ on body weight gain and food consumption were similar in all groups compared with control group.

In addition, the data obtained are not consistent with Trnqvist, 1997 who found a decrease in body weight gain per day in rats exposed to 5$10 \mathrm{mg}$ acrylamide $/ \mathrm{kg}$ body weight. While the dose of acrylamide in our experiment was less than the dose used by him, and our findings have cleared that the concentration of acrylamide was $0.3 \mathrm{~g} / \mathrm{kg}$ of the sample and over toasted bread in the diet was ten percent (10\%).

Table (6): Effect of (over toasted bread) and ginger and garlic extracts on body weight gain, daily food intake and food conversion ratio in rats:

\begin{tabular}{|c|c|c|c|c|}
\hline parameters Treatments & \begin{tabular}{|} 
Final body \\
weight gain \\
(g)
\end{tabular} & \begin{tabular}{|c|}
$\begin{array}{c}\text { Daily body } \\
\text { weight gain } \\
\text { (g) }\end{array}$ \\
\end{tabular} & $\begin{array}{l}\text { Daily food } \\
\text { intake }(g)\end{array}$ & $\begin{array}{l}\text { Food } \\
\text { conversion } \\
\text { ratio (FCR) }\end{array}$ \\
\hline Group (1) :Basal diet (-control) & $70.33^{\text {ba }}$ & $2.34^{\text {ba }}$ & $16.47^{\mathrm{a}}$ & $7.69^{b}$ \\
\hline $\begin{array}{l}\text { Group (2): Basal diet }+10 \% \\
\text { over toasted bread(+control) }\end{array}$ & $73.67^{\mathrm{a}}$ & $2.46^{a}$ & $18.42^{\mathrm{a}}$ & $8.01^{\mathrm{b}}$ \\
\hline $\begin{array}{l}\text { Group (3) :+ control diet + } \\
\text { ginger extract } 50 \mathrm{mg} / \mathrm{K} . \mathrm{g} \text { b.w }\end{array}$ & $55.83^{\text {bac }}$ & $1.86^{\mathrm{bac}}$ & $18.46^{\mathrm{a}}$ & $10.72^{\text {ba }}$ \\
\hline $\begin{array}{l}\text { Group (4): + control diet + } \\
\text { ginger extract } 100 \mathrm{mg} / \mathrm{K} . \mathrm{g} \text { b.w }\end{array}$ & $49.83^{\mathrm{bac}}$ & $1.66^{\mathrm{bac}}$ & $18.66^{\mathrm{a}}$ & $15.28^{\mathrm{ba}}$ \\
\hline $\begin{array}{l}\text { Group (5): + control diet + garlic } \\
\text { extract } 200 \mathrm{mg} / \text { K.g b.w }\end{array}$ & $65.16^{\text {ba }}$ & $2.17^{\text {ba }}$ & $17.08^{\mathrm{a}}$ & $8.63^{b}$ \\
\hline $\begin{array}{l}\text { Group (6): + control diet + garlic } \\
\text { extract } 400 \mathrm{mg} / \text { K.g b.w }\end{array}$ & $49 \mathrm{ba}^{\mathrm{c}}$ & $1.63^{\mathrm{bac}}$ & $16.61^{a}$ & $11.62^{\text {ba }}$ \\
\hline P. Value: & 0.09 & 0.09 & 0.20 & 0.14 \\
\hline L.S.D: & 26.78 & 0.89 & 2.38 & 8.86 \\
\hline & N.S & N.S & N.S & N.S \\
\hline
\end{tabular}

L.S.D: Least significant difference.

N.S: Non significant at $P>0.05$

b.w: Body weight.

a, b and c: Means within the same column with different superscripts are significant 
Effect of (over toasted bread) and ginger and garlic extracts on hemoglobin, hematocrit and total antioxidant capacity:

Data in Table (7) illustrated that hemoglobin and hematocrit were decreased in the positive group compared with the negative group, and the values were $12.23 \mathrm{~g} / \mathrm{dl}$ and $37.67 \%$ for hemoglobin and hematocrit, respectively. The highest value was $14.21 \mathrm{~g} / \mathrm{dl}$ for hemoglobin in negative group but the lowest value was $12.23 \mathrm{~g} / \mathrm{dl}$ in positive group, while the fourth group which contains ginger extract at dose of $100 \mathrm{mg} / \mathrm{k} . \mathrm{g}$ body weight and sixth group which contains garlic extract at dose of $400 \mathrm{mg} / \mathrm{kg}$ b.w had values of $(14.05$ and $14.03 \mathrm{~g} / \mathrm{dl})$, respectively.

For hematocrit, our results have shown that the highest value was $43.62 \%$ in the negative group, but the lowest value was $37.67 \%$ in the positive group. The groups which followed the highest value were the fourth group which contains ginger extract at a dose of $100 \mathrm{mg} / \mathrm{k} . \mathrm{g}$ body weight. Our results showed high significant difference among the groups compared with the positive group $P<0.01$. In the present study ginger extract and garlic extract proved that they have got therapeutic effect for increasing both hemoglobin and hematocrit to normal level.

Ballat and Smith ( 1992) reported that garlic extract protect the erythrocytes membrane against oxidative stress inhibiting the formation of abnormally dense erythrocytes which are believed to play an important role in the clinical manifestations of sickle cell anaemia patients, the previous result supports our results for influential effect of garlic extract.

With respect to total antioxidant capacity for serum, our results have shown non significant difference among groups compared with a positive group $\mathrm{P}>0.05$.

Our results did not agree with Afshari et al., (2007) who illustrated that plasma antioxidant capacity in diabetic treated with ginger group was higher when compared with positive and negative groups. The contradiction may be due to the difference in concentration of ginger and chemical analysis, on the other hand our results agreed with Shati et al., (2009) who found that water extract of ginger with alcohol showed no significant changes in total antioxidant capacity for serum and significant changes in total antioxidant capacities in liver and kidney tissues when compared with the control group.

On the other hand Benkeblia, 2004 claimed that organic and aqueous extracts of garlic had significant antioxidant potential. But our results have shown the treatment of garlic extract at $400 \mathrm{mg} / \mathrm{k} . \mathrm{g}$ body weight per day increased the antioxidant capacity from $1.64 \mathrm{mmol} / \mathrm{L}$ in a positive group to $1.94 \mathrm{mmol} / \mathrm{L}$ but no significant increase $\mathrm{P}>0.05$. 
Table (7) Effect of (over toasted bread) and ginger and garlic extracts on hemoglobin, hematocrit and total antioxidant capacity.

\begin{tabular}{|l|c|c|c|}
\hline \multicolumn{1}{|c|}{ Treatments } & $\begin{array}{c}\text { Hemoglobin } \\
\text { g/dl }\end{array}$ & $\begin{array}{c}\text { Hematocrit } \\
\%\end{array}$ & $\begin{array}{c}\text { Total } \\
\text { antioxidant } \\
\text { capacity } \\
\text { mmol/L }\end{array}$ \\
\hline Group (1): Basal diet (control) & $14.21^{\mathrm{a}}$ & $43.62^{\mathrm{a}}$ & $1.94^{\mathrm{a}}$ \\
\hline $\begin{array}{l}\text { Group (2): Basal diet +10\% over } \\
\text { toasted bread (+control) }\end{array}$ & $12.23^{\mathrm{b}}$ & $37.67^{\mathrm{b}}$ & $1.64^{\mathrm{a}}$ \\
\hline $\begin{array}{l}\text { Group (3): (+Control) diet + ginger } \\
\text { EX (50mg/K.g b.w) }\end{array}$ & $14.00^{\mathrm{a}}$ & $43.00^{\mathrm{a}}$ & $1.94^{\mathrm{a}}$ \\
\hline $\begin{array}{l}\text { Group (4): (+Control) diet + ginger } \\
\text { EX (100mg/K.g b.w) }\end{array}$ & $14.05^{\mathrm{a}}$ & $43.13^{\mathrm{a}}$ & $1.90^{\mathrm{a}}$ \\
\hline $\begin{array}{l}\text { Group (5): (+Control) diet +garlic } \\
\text { EX (200mg/K.g b.w) }\end{array}$ & $13.90^{\mathrm{a}}$ & $42.69^{\mathrm{a}}$ & $1.98^{\mathrm{a}}$ \\
\hline $\begin{array}{l}\text { Group (6): (+Control) diet+garlic EX } \\
\text { (400mg/K.g b.w) }\end{array}$ & $14.03^{\mathrm{a}}$ & $43.07^{\mathrm{a}}$ & $1.92^{\mathrm{a}}$ \\
\hline P. value & 0.003 & 0.003 & 0.96 \\
\hline L.S.D & 0.95 & 2.86 & 0.56 \\
\hline & $\star *$ & $\star *$ & $\mathrm{~N} . \mathrm{S}$ \\
\hline
\end{tabular}

a, $b$ and $c$ : Means within the same column with different superscripts are significant. L.S.D: Least significant difference

N.S: Non significant $(P>0.05)$

EX.: extract

b.w: Body weight

**: high significant $(p<0.01)$

Effect of (over toasted bread) and antioxidant ginger and garlic extracts on liver functions:

Table (8) showed the effect of over toasted bread and antioxidant plant extracts on liver functions in rats, the data showed that the positive group had high significant increase in GPT and GOT. Ginger and garlic extracts could decrease liver serum enzymes in all groups from group (3) to group (6). There was a very high significant change among all groups compared with positive group $\mathrm{P}<0.0001$.

It could be seen from Table (8) that the highest value was observed in the positive group (96.85) and $144.48 \mathrm{U} / \mathrm{L}$ ) for GOT and GPT, respectively.

But the lowest value for GPT was $44.47 \mathrm{U} / \mathrm{L}$ in the sixth group treated with garlic extract at dose of $400 \mathrm{mg} / \mathrm{k} . \mathrm{g} \mathrm{b}$.w followed by group (4) treated with ginger extract at dose of $100 \mathrm{mg} / \mathrm{kg} \mathrm{b.w}$ and its value was $45.65 \mathrm{U} / \mathrm{L}$. So, the garlic extract was the best for reducing GPT enzyme. For GOT enzyme, our obtained results have shown the lowest value in negative group followed by the sixth group with value of $41.75 \mathrm{U} / \mathrm{L}$ treated with garlic extract at dose of $400 \mathrm{mg} / \mathrm{k} . \mathrm{g} /$ day, and fifth group treated with garlic extract at dose of $200 \mathrm{mg} / \mathrm{k}$.g body weight / day. So, It could be summarized that garlic extract was the best extract to reduce high levels of GOT and GPT in blood serum.

From the same table there was not significant difference between the groups and positive group $(P>0.05)$ for total protein. It was noticed that over toasted bread containing acrylamide reduced significantly protein, albumin and globulin and the ratio between albumin and globulin in the positive 
control, and the extracts led to increase total protein, albumin and globulin , and albumin /globulin ratio, but the increase was not significant compared with the negative control group ( $p>0.05$.)

Our results are in accordance with Gedik et al.,2005 who reported that garlic extract could decrease the high levels of serum AST (GOT) and ALT (GPT) in the BDL (Bile duct legation and scission) rats group and the results were significant compared with the positive $(B D L)$ group $P<0.01$.

And also our results agreed with Shati et al., (2009) who showed that ginger extract alleviated of the high levels of liver serum enzymes (GOT ,GPT)and their values were in alcohol group $(121.9,133)$ respectively, after using ginger extract liver enzymes were significantly reduced to 58 and 75.2 for GOT ,GPT ,respectively and also bilirubin was elevated in alcohol group ,but the ginger extract could significantly reduce bilirubin from 11.9 to 6.6 .

Table (8) Effect of (over toasted bread) and ginger and garlic extracts on liver functions:

\begin{tabular}{|c|c|c|c|c|c|c|}
\hline Treatments & $\begin{array}{l}\text { GOT } \\
\text { U/L }\end{array}$ & $\begin{array}{l}\text { GPT } \\
\text { U/L }\end{array}$ & $\begin{array}{l}\text { Total } \\
\text { protein } \\
\text { g/dl }\end{array}$ & $\begin{array}{c}\text { Albumin } \\
\text { g/dl }\end{array}$ & $\begin{array}{c}\text { Globulin } \\
\text { g/dl }\end{array}$ & $\begin{array}{l}\text { Ratio } \\
\text { between } \\
\text { albumin } \\
\text { and } \\
\text { globulin }\end{array}$ \\
\hline $\begin{array}{l}\text { Group (1): Basal diet } \\
\text { (-control) }\end{array}$ & $37.68^{\mathrm{C}}$ & $47.29^{c}$ & $6.25^{\mathrm{a}}$ & $4.36^{\mathrm{a}}$ & $1.88^{\mathrm{a}}$ & $2.32^{a}$ \\
\hline $\begin{array}{l}\text { Group (2): Basal diet } \\
+10 \% \text { over toatted bread } \\
(+ \text { control) }\end{array}$ & $96.85^{\mathrm{a}}$ & $144.48^{a}$ & $5.30^{\mathrm{b}}$ & $3.70^{\mathrm{b}}$ & $1.60^{\mathrm{b}}$ & $2.32^{a}$ \\
\hline $\begin{array}{l}\text { Group (3): (+control) diet } \\
+ \text { ginger EX (50mg/k.g } \\
\text { b.w) }\end{array}$ & $45.10^{\mathrm{cb}}$ & $68.19^{b}$ & $5.92^{\mathrm{ba}}$ & $4.09^{\mathrm{ba}}$ & $1.83^{\mathrm{ba}}$ & $2.25^{\mathrm{a}}$ \\
\hline $\begin{array}{l}\text { Group (4): (+control) diet+ } \\
\text { ginger EX (100mg/k.g } \\
\text { b.w) }\end{array}$ & $44.72^{\mathrm{cb}}$ & $45.65^{\mathrm{c}}$ & $6.14^{\mathrm{a}}$ & $4.29^{a}$ & $1.85^{\mathrm{ba}}$ & $2.32^{\mathrm{a}}$ \\
\hline $\begin{array}{l}\text { Group (5): (+control) diet+ } \\
\text { garlic EX (200mg/K.g } \\
\text { b.w) }\end{array}$ & $42.60^{c b}$ & $65.53^{b}$ & $5.91^{\text {ba }}$ & $4.03^{\mathrm{ba}}$ & $1.89^{\mathrm{a}}$ & $2.18^{\mathrm{a}}$ \\
\hline $\begin{array}{l}\text { Group (6): (+control) diet } \\
+ \text { garlic EX (400mg/k.g } \\
\text { b.w) }\end{array}$ & $41.75^{\mathrm{cb}}$ & $44.47^{\mathrm{C}}$ & $5.94^{\mathrm{ba}}$ & $4.05^{\mathrm{ba}}$ & $1.89^{\mathrm{a}}$ & $2.31^{a}$ \\
\hline P-value & $<0.0001$ & $<0.0001$ & 0.16 & 0.23 & 0.42 & 0.99 \\
\hline L.S.D & 7.82 & 11.54 & 0.69 & 0.55 & 0.27 & 0.45 \\
\hline & $* \star *$ & $\star \star \star$ & N.S & N.S & N.S & N.S \\
\hline
\end{tabular}

GPT: Glutamic pyruvic Transaminase.

GOT: Glutamic oxalacetic transaminase.

a, b and c: Means with in the same column with different superscripts are significant N.S: Non significant $(P>0.05)$

${ }^{* \star \star}$ : very high significant at $(P<0.001)$.

EX: Extract 
Effect of (over toasted bread) and antioxidant ginger and garlic extracts on lipid profile, glucose level and Superoxide dismutase (SOD):

From Table (9) our results have shown non significant change in glucose for all groups compared with the positive group control in glucose level thus, it could be noticed that acrylamide found in over toasted bread did not affect the glucose level in blood serum. So, effect of ginger and garlic extracts did not appear through the trial. The best extract was ginger rhizomes extract at dose of $100 \mathrm{mg} / \mathrm{k} . \mathrm{g}$ body weight and it could decrease the glucose level from $91.65 \mathrm{mg} / \mathrm{dl}$ in positive group to $85.58 \mathrm{mg} / \mathrm{dl}$ but the reduction was not significant $P>0.05$. Also our results did not agree with Ahmed, (1994) who reported that acrylamide caused an increase in glucose level and the disagreement due to the difference in amount of acrylamide.

Our results showed that the highest value of triglycerides was 105.23 $\mathrm{mg} / \mathrm{dl}$ in the positive group, whereas the lowest value was observed for triglycerides was $76.55 \mathrm{mg} / \mathrm{dl}$ in group (6) treated with garlic extract at dose of $400 \mathrm{mg} / \mathrm{k}$. g body weight per day, followed by group (4) which contains ginger extract at a dose of $100 \mathrm{mg} / \mathrm{k}$. g body weight per day. With respect to total cholesterol, the obtained results have shown that the highest value was $157.81 \mathrm{mg}$ cholesterol / $\mathrm{dl}$ in the positive group then the value decreased to $91.18 \mathrm{mg}$ cholesterol / $\mathrm{dl}$ in the sixth group treated with garlic extract at a dose of $400 \mathrm{mg} / \mathrm{k}$. g body weight daily. It was noticed that garlic extract decreased the high levels of total cholesterol and triglycerides in blood serum. In general, there was a very high significance among all groups compared with positive group $\mathrm{P}<0.0001$. Al - Amin et al., 2006 reported that raw ginger at dose of $500 \mathrm{mg} / \mathrm{k}$. g was significantly effective in lowering cholesterol and triglycerides levels in the ginger -treated diabetic rats.

From Table (9) our obtained results showed that the highest value of LDL was $90.72 \mathrm{mg} / \mathrm{dl}$ in the positive control, while the lowest value was $31.96 \mathrm{mg} / \mathrm{dl}$ in the negative control followed by group (6) treated with garlic extract at a dose of $400 \mathrm{mg} / \mathrm{k}$. g body weight daily. So, the best treatment was garlic extract that could decrease LDL $-\mathrm{C}$ from $90.71 \mathrm{mg} / \mathrm{dl}$ to 35.38 $\mathrm{mg} / \mathrm{dl}$ in group (6). With regard to $\mathrm{HDL}-\mathrm{C}$ our results showed that extracts could decrease HDL - C except group (5) which contains garlic extract at dose of $200 \mathrm{mg} / \mathrm{kg}$ b.w compared with the positive control $(P<0.0002)$.

The highest value was $46.23 \mathrm{mg} / \mathrm{dl}$ in group (5) followed by the positive control and its value was $46.04 \mathrm{mg} / \mathrm{dl}$. It was concluded that acrylamide caused significant increase for HDL - C compared with negative control. Our result did not agree with many authors such as Durak et al., 2004 who reported that garlic extract increased HDL-C level.

Also, our results showed that the highest value of VLDL was $21.04 \mathrm{mg}$ / dl in positive control (2), while the lowest value was 15.31 in group (6) which was treated with garlic extract at a dose of $400 \mathrm{mg} / \mathrm{k}$. g body weight daily, followed by group (4) treated with ginger extract at a dose of $100 \mathrm{mg}$ /k.g b.w daily.

There was a very high significant change among all groups compared with the positive control $(P<0.0001)$. 
Gehan A.Goneim et al.

9

884 
It was noticed that the best extract was garlic extract in sixth group and acrylamide caused a significant increase for VLDL compared with negative group. Our results are in agreement with Durak et al., (2004) who claimed that serum total cholesterol, LDL-C, V - LDL -C, triglycerides levels and total / high - density lipoprotein cholesterol ratios were found to be significantly lowered after use of garlic extract at a dose of $1 \mathrm{ml}$ per $\mathrm{k}$. $\mathrm{g}$ of body weight daily for four months. In addition Al-Amin et al ., (2006) reported that raw ginger at a dose of $500 \mathrm{mg} / \mathrm{k.g}$ was significantly effective in lowering cholesterol and triglycerides levels in the ginger -treated diabetic rats .

Also from our results in Table (9) it could be seen that the highest value of SOD was $81.93 \%$ in the negative control, while the lowest value was $44.28 \%$ in positive control which contains only over toasted bread. So the present study has suggested that acrylamide led to decrease SOD. After the treatment with the extracts from group (3) to group (6), SOD increased compared with the positive control $\mathrm{P}<0.0001$. The best extract in increasing SOD enzyme was garlic extract at dose of $400 \mathrm{mg} / \mathrm{k} . \mathrm{g}$ body weight daily in group (6) and its values was $65.88 \%$. Our results agreed with EL sharaky et al., (2009) who reported that the administration of ginger extract at a dose of $100 \mathrm{mg} / \mathrm{k} \mathrm{g}$ showed (SOD)enzyme activity was increased in liver tissues to $7 \mathrm{U} / \mathrm{mg}$ protein compared with the level of SOD enzyme in bromobenzene control group ( $4 \mathrm{U} / \mathrm{mg}$ protein ). SOD is an important cellular antioxidant enzyme, which converts superoxide radical into $\mathrm{H}_{2} \mathrm{O}$ and $\mathrm{O}_{2}$.

And also Dat and Tapat (2009) illustrated that SOD activity was decreased by $25-30 \%$ when compared with normal control group, but water garlic infusion increased SOD by $(25 \%, \mathrm{P}<0.001)$ compared with carcinogen DMBA group and it is known that 7.12 - Dimethylbenz (a) anthracene (DMBA) causes skin carcinogenesis when it is injected into rats.

\section{REFERANCES}

A . O . A . C . (2009) : Official Methods of Analysis of the Association of official Analytical Chemists . Washington D.C.,U.S.A.

A. O. A. C. (2000) : Official Methods of Analysis of the Association of Official Analytical Chemists . Washington D.C.,U.S.A.

Afshari A.,T., Alireza Shirpoor, Amirabbas Farshid,and Ramin saadatian, (2007). The effect of ginger on diabetic nephropathy, plasma antioxidant capacity and lipid peroxidation in rats. Food Chemistry 101, 148-153.

Ahmed, A.E. (1994): Chemical and biological studies on monosodium glutamate. Ph. D. Thesis. Department of science and Education. Faculty of Women. Ain Shams University.

Al-Amin, Z. M., Thomson, M., Al- Qattan, K.K., Peltonen - Shalaby, R. and Ali, M., 2006. Anti - diabetic and hypolipidaemic properties of ginger in streptozotocin induced diabetic rats. Br. J. Nutr. 96, $660-666$.

Al-Numair, K.S., 2009. Hypocholesteremic and antioxidant effects of garlic (Allium Sativum L.) extract in rats fed high cholesterol diet. Pak. J. Nutr. 8-161-166.

Ballat, S.K., \& Smith, E. D. (1992). Red cell changes during the evolution of the sickle cell painful crisis. Blood, 79, $2154-2163$. 
Beachamp C , and Fridovich , (1971) . Superoxide dismutase : improved assays and an assay applicable to acrylamide gels. Anal Biochem , Nov ; 44 (1) : $276-87$.

Benkeblia, N. (2004). Antimicrobial activity of essential oil extracts of various onions (Allium cepa) and garlic ( $A$. Sativum). Lebensm-wiss Technology, 37, 263- 268.

Bhandari, U., Sharma, J.N., and Zafar, R., 1998. The protective action of ethanolic ginger extract in cholesterol fed rabbits. J. Ethanopharmacol. 61(2). 167- 171.

Blumenthal, M. (2000).Herbal medicine: expanded commission E monographs .Newton, MA: Integrative Medicine communications (HAS Library), 53p.

Bozin B., Neda Mimica, Dukic., Isidora Samojlik, Anackov Goran,and Ruzica. (2008) Phenolics as antioxidants in garlic (Allium Sativum L., Alliaceae). Food Chemistry 111 (925 - 929.

Ceylen ,E.and Fung ,D.Y.C.(2004)Antimicrobial activity of spices. Journal of rapid Methods and Automation in Microbiology12:1-55.

Costax L.G., H. Deng, C. Gregotti, L. Manzo, E.M. Faustman, E. Bergmark, and C.J. calleman, (1992) The acrylamide is a potential genetic and reproductive toxin. Neurotoxicology $13-219$.

Dat I., Ph. D. and Tapat Saha, Ph. D. (2009) Effect of garlic on lipid peroxidation and antioxidation enzymes in DMBA - induced skin carcinoma Nutrition $25-459-471$.

Dearfield K.L. , G.R. Douglas, U.H. Ehling, M. M. Moore, G.A. and Sega, D.J. (1995) Acrylamide: a review of its genotoxicity and an assessment of heritable genetic risk Brusick, Mutat. Res. $330-471$.

Dedov, V.N., Tran, V.H., Duke, C.C., Connor, M., Christie, M.J., Mandadi, S., and Roufogalis, B.D., (2002). Gingerols: anovel class of vanilloid receptor (VR1) agonists. Br. J. Pharmacol. 137, $793-798$.

Dong, Z. (2000): Effects of food factors on signal transduction pathways Biofactors. 12(1-4):17-28.

Doumas, B.T., Watson, W.A., and Biggs, H.G.(1971). Albumin standerds and the measurement of serum albumin with bromcresol green. Clin. Chim Acta:31-87.

Durak I., Mustafa Kavutch, Bilal Aytaç, Aslihan AVCL, Erdinç Devim, Hanefiözbek, and Hasan serdar öztürk., (2004). Effects of garlic extract consumption on blood lipid and oxidant/antioxidant parameters in humans with high blood cholesterol. Journal of Nutritional Biochemistry 15, 373-377.

El-Sharaky, A.S., A.A. Newairy, M.A.Kamel, and S.M. Eweda (2009). Protective effect of ginger extract against bromobenzene-induced hepatotoxicity in male rats Food and Chemical Toxicology 47, 15841590.

Finley PR. Ronald B. Schifrnan , R.Jane Williams and Donald A. lichti. (1978). Determination of high -density lipoprotein cholesterol Clin Chem. $24: 931$. 
Franco RS. Hemoglobin and Kaplan A, 1984 Determination of Hemoglobin in blood serum (colorimetric test). Clin Chem The C.V. Mosby Co. St Louis. Toronto. Princeton; $1294-1296$ and 418.

Friedewald WT, Robert levy and Don (1972). Mrasurement of low density lipoprotein cholesterol in blood serum., Clin Chem 18:499.

Gedik N., Levent Kabasakal, ozer sehirli, Feriha Ercan, and Serap, S.C. (2005). Long-term administration of aqueous garlic extract (AGE) alleviates liver fibrosis and oxidative damage induced by biliary obstruction in rats. Life Sciences 76. 2593-2606.

Ghoneim ,G. A. (2012) Effect of various levels of ginger and sumac on the quality of fresh beef sausage during refrigerated storage . J.food and Dairy Sci ., Mansoura Univ., vol. $3: 173-184,2012$.

Gorinstein S., Maria Leontowicz, Hanna Leontowicz, Katarzyna Najman, Jacek Namiesnik, Y.S. Park, S.T. Jung, S.G. Kang,and S. Traktenberg (2006). Supplementation of garlic lowers lipids and increases antioxidant capacity in plasma of rats. Nutrition Research $26-362-$ 368.

Goupy,p.,Hugues , M.Boivin,p.andAmoit,M.(1999).Antioxidant composition and activity of barley (Hordeum vulgare) and malt extracts and of isolated phenolic compounds .J.Sci. Food Agric ., 79 : $1625-1634$.

Gusev ,S.P. and Grishina (1963) :The compositions of different varieties of garlic.Tr.Mosk. In St.Nar .Khoz(24),30-4-(C.F.Chem.Abest.62:1012g.1965)

Horie, T., Murayama, T., Mishima, T., Itoh, F., Minadine, Y., Fuwa, T., and Awazu, S., 1989. Protection of liver microsomal membranes from lipid peroxidation by garlic extract. Planta Med. 55, 506.

IFCC: (1977) International Federation of clinical Chemistry. Provisional Recommendations on IFCC Methods for the Measurement of catalytic concentrations of Enzymes. Method for Aspartate Amino-transferance. Clin Chem 23:887.

Inory MC (1954) : Amicrohematocrit for determining the packed cell hemoglobin concentration on capillary blood . J. clin . path ., $7: 32$.

lqbal S. , M.I. Bhanger., (2007) .Stabilization of sun flower oil by garlic extract during accelerated storage . Food Chemistry , 100,246-254 .

Ivanova V.,Marina stefova and Fabio chinnici (2010).Determination of polyphenol contents in Macedonian grapes and wines by standardized spectrophotometric methods .J.serb . Chem .Soc.75,(1)45-59 JSCS3940

Koracevic, D., Koracevic, G., and D jord je vic V, (2001) Method for the measurement of total antioxidant activity in human fluids.J. Clin. Pathol. $54,356-361$.

Leighton T., C.Ginther, L. Fluss, W.K. Harter, J. Cansado, V.Notaro, in: M.T. Haung C.T. Ho and C.Y. Lee (EdS.),(1992) Phenolic compounds from Food and Their Effects on health American Chemical Society Symp. Ser, Vol. 507, P. 220.

Mattila P. ,J.Astola,J.Kumpulianen .,(2000):Determination of flavonoids in plant material by HPLC with diode-array and electro - array detections . J. Agric . Food Chem. ., 48: $5834-5841$. 
Miean K.H. , and S. Mohamed, (2001). Flavonoids content of 62 vegetables and some plants. J. Agri. Food Chem. 49 (6) 3106.

Mustafa, T; Srivattava, K.C. and Jensen, K. B. (1993): Drug Development Report (9): Pharmacology of ginger, zingiber officinale. J. Drug Dev., 6 $: 24$.

Oboh G. , Ayodele J. Akinyemi, Adedayo O. and Ademiluyi., (2010). Antioxidant and inhibitory effect of red ginger (zingiber officinale var. Rubra) and White ginger (Zingiber officinale Roscoe) on $\mathrm{Fe}^{+3}$ induced lipid peroxidation in rat brain in vitro. Experimental and Toxicologic Pathology 1-6.

Pencock CA; H. Schwartz , T.H ., and passkey, T.A. Murphy , and D., sellers. (1973) Evaluation of an Enzymatic procedure for determination of serum glucose. Clin Chem. Acta $₫ 49: 193$.

Reeves P.,G., forrest H.Nielsen and George C.and Fahey, JR.(1993)

AIN-9 purified Diets for laboratory Rodents :Final Report of the American Institute of Nutrition Ad Hoc writing committee on the Reformulation of the AIN - 76 A Rodent Diet . Committee Report .Journal of American Institute of Nutrition . 123:1939 - 1951.

Reitman , S., and Frankel , and S., Amer (1957). Acolorimetric method for the determination of serum glutamic pyruvic transaminase (GPT). J. Clin . Path ., 195; 28:56 .

Rong X., Gang Peng, Takuya Suzuki, Qinglin Yang, Johji Yamahara, and Yuhao Li., (2009). A 35 - day gavage safety assessment of ginger in rats. Regulatory Toxicology and pharmacology 54, 118 - 123.

SAS (1996)SAS; User's Guide :statistics .Version 6.1.SAS Institute. Inc., Cary, NC ,USA Schultz A. Uric acid. Kaplan A et al . Clin Chem The C.V. Mosby Co. St louis . Toronto. Princeton 1984;1261 - 1266 and 418.

Shati A.A., Fahmy G.and Elsaid., (2009) Effects of water extracts of thyme (Thymus valgaris) and ginger (Zingiber officinale Roscoe) on alcohol abuse. Food and Chemical Toxicology 47, 1945-1949.

Shukla, Y., and Singh, M., (2007). Cancer preventive properties of ginger: Abrief review. Food Chem.. Toxicol. 45, $683-690$.

Tietz , N.W. (1970) Fundamentals of Clinical Chemistry , Saunders Co . Philadelphia, PA 302 .

Tilson H.A., Neurobehav (1981). The neurotoxicity of acylamide. Toxicol. Teratol. $3-445$.

Trinder , P (1969).. Determination of Glucose in Blood using Glucose oxidase with an Alternative oxygen Acceptor. Ann Clin Biochem 6.24-25

Trnqvist, K. (1997): Factors influencing acrylamide content and color in rye crisp bread. Indian J. Exp. Biol. 1997 Apr; 42 (4): 389 - 97.

Wang Haiyan , Albert W.M.Lee,Shaomin Shuang , and Martin M.F.Choi. (2008)SPE/HPLC/UV studies on acrylamide in deep-fried flour-based indigenous Chinese foods. Microchemical Journal ;89-90-97.

Weidner, M.S., and Sigwart, K., (2000). The safety of a ginger extract in the rat. J. Ethnopharmacol. $73,513-520$. 
Youssef , A.K .,Aboul . Enein , A.M. Osman S.A. and Hewedi F.M.(1995): Chemical analysis of Egyptian onion and garlic extract . Ain Shams Univ.,Agric.SCi Bull. Vol. 1968, issue March, pp. 1980

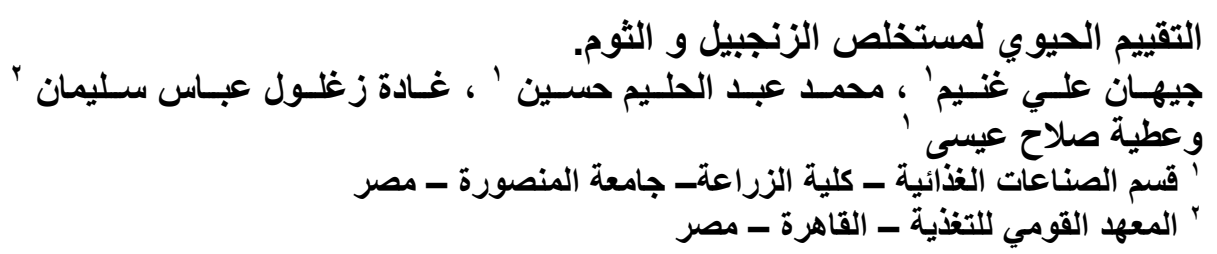

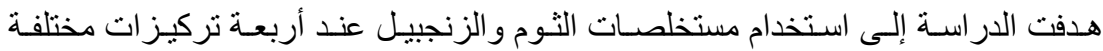

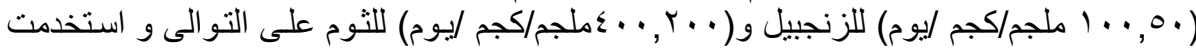

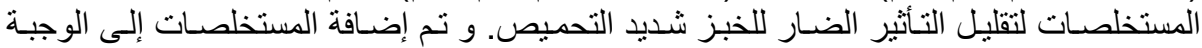

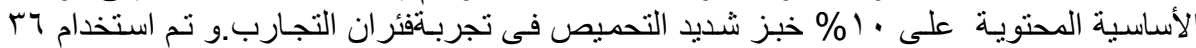

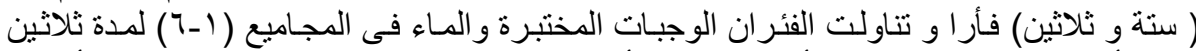

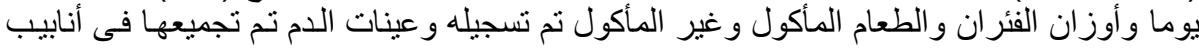

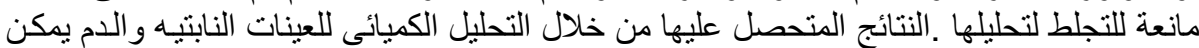

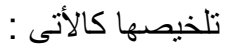

أوضحت النتائج أن عينة الزنجبيل أحتوت على أعلى نسبة من الكربو هيدرات الكليه و الدهن

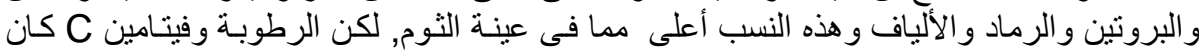

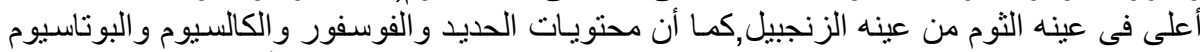

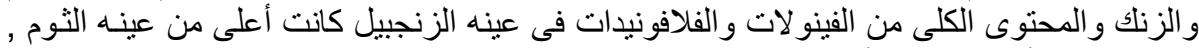

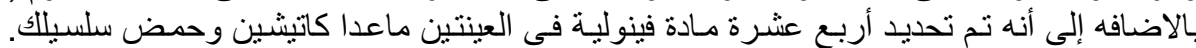

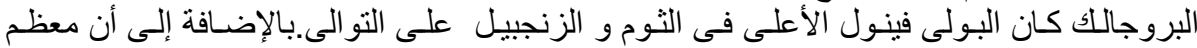

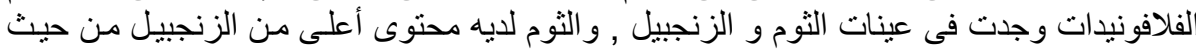

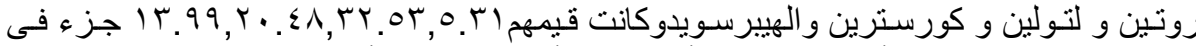

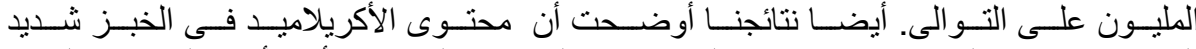

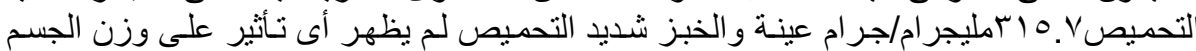

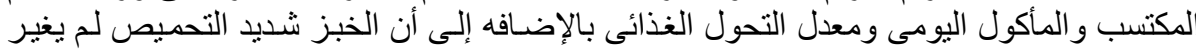

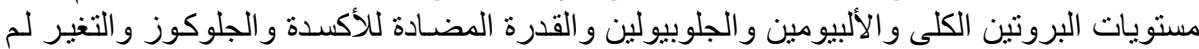

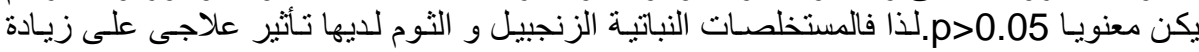

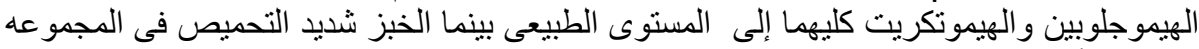

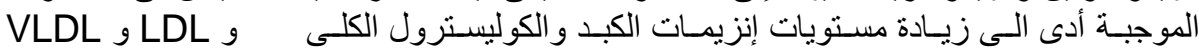

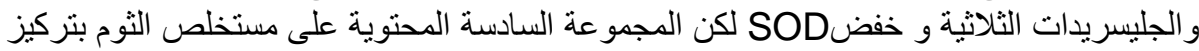

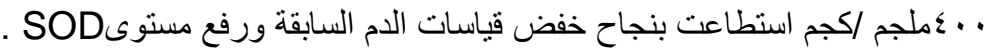


Table (9): Effect of (over toasted bread) and antioxidant ginger and garlic extracts on lipid profile, glucose level and Superoxide dismutase (SOD):

\begin{tabular}{|c|c|c|c|c|c|c|c|}
\hline Treatments parameters & $\mathrm{TG} \mathrm{mg} / \mathrm{dl}$ & $\begin{array}{c}\text { Total } \\
\begin{array}{c}\text { Cholesterol } \\
\text { mg/dl }\end{array}\end{array}$ & $\begin{array}{c}\mathrm{HDL}-\mathrm{C} \\
\mathrm{mg} / \mathrm{dl}\end{array}$ & $\begin{array}{l}\text { L-D-L-C } \\
\text { mg/dl }\end{array}$ & $\begin{array}{l}\text { VLDL-C } \\
\text { mg/dl }\end{array}$ & $\begin{array}{l}\text { Glucose } \\
\mathrm{mg} / \mathrm{dl}\end{array}$ & SOD $\%$ \\
\hline $\begin{array}{l}\text { Group(1) : Basal diet } \\
(- \text { control) }\end{array}$ & $80.63^{\mathrm{cb}}$ & $89.35^{c}$ & $41.26^{b}$ & $31.96^{d}$ & $16.13^{\mathrm{cb}}$ & $83.53^{\mathrm{a}}$ & $81.93^{a}$ \\
\hline $\begin{array}{l}\text { Group }(2) \text { : Basal diet }+10 \% \text { over toasted } \\
\text { bread (+control) }\end{array}$ & $105.23^{\mathrm{a}}$ & $157.81^{a}$ & $46.04^{\mathrm{a}}$ & $90.72^{\mathrm{a}}$ & $21.04^{\mathrm{a}}$ & $91.65^{\mathrm{a}}$ & $44.28^{d}$ \\
\hline $\begin{array}{l}\text { Group(3) : (+ control) diet + ginger EX (50mg } \\
\text { k. g b. w ) }\end{array}$ & $84.80^{\mathrm{b}}$ & $99.95^{\mathrm{C}}$ & $38.54^{b}$ & $44.46^{\mathrm{cb}}$ & $16.95^{\mathrm{b}}$ & $85.87^{\mathrm{a}}$ & $53.36^{c}$ \\
\hline $\begin{array}{l}\text { Group (4) : (+control) diet+ ginger EX } \\
(100 \mathrm{mg} / \mathrm{k} . \mathrm{g} \text { b.w) }\end{array}$ & $78.17^{\mathrm{cb}}$ & $94.19^{c}$ & $38.65^{b}$ & $39.91^{\mathrm{cd}}$ & $15.63^{\mathrm{cb}}$ & $85.58^{a}$ & $62.15^{\mathrm{b}}$ \\
\hline $\begin{array}{l}\text { Group (5) : (+control)diet+ garlic EX } \\
(200 \mathrm{mg} / \mathrm{K} . \mathrm{g} \text { b.w) }\end{array}$ & $79.13^{\mathrm{cb}}$ & $118.24^{b}$ & $46.23^{\mathrm{a}}$ & $55.53^{b}$ & $15.82^{\mathrm{cb}}$ & $86.58^{a}$ & $51.39^{c}$ \\
\hline $\begin{array}{l}\text { Group (6) (+control) diet + garlic EX } \\
(400 \mathrm{mg} / \mathrm{k} . \mathrm{g} \mathrm{b.w})\end{array}$ & $76.55^{\mathrm{C}}$ & $91.18^{C}$ & $38.32^{b}$ & $37.56^{\mathrm{cd}}$ & $15.31^{\mathrm{c}}$ & $89.59^{a}$ & $65.88^{b}$ \\
\hline P-value & $<0.0001$ & $<0.0001$ & $<0.0002$ & $<.0001$ & $<0.0001$ & 0.80 & $<0.0001$ \\
\hline L.S.D & 8.15 & 13.31 & 3.92 & 11.71 & 1.63 & 9.8 & 5.8 \\
\hline & 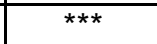 & $\star \star \star *$ & 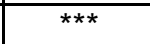 & $\star \star \star *$ & 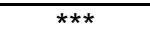 & N.S & 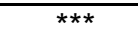 \\
\hline
\end{tabular}

HDL-C: High density lipoprotein cholesterol SOD: Superoxide dismutase VLDL-C: Very low density lipoprotein cholesterol.

L.S.D.: Least significant difference.

$* * *$ : Very high significant at $(P<0$ 